\title{
Analysis of Cash Internal Control System Application in Paripurna Masjid of Pekanbaru
}

\author{
Abrar* Raja Ade Fitrasari Mochtar Dian Saputra \\ Faculty of Economic, Universitas Islam Riau, Pekanbaru, Riau, Indonesia
}

\begin{abstract}
The background of this study is to realize the vision of Pekanbaru city as a civilized metropolitan city so it is necessary to establish a Paripurna Masjid as the spearhead of religious and community life development. Sources of funding in fostering and managing the Paripurna Mosque (Masjid) can be taken from Riau Province Regional Revenue and Expenditure Budget and Pekanbaru Revenue and Expenditure Budget.

Sources of Paripurna Mosque (Masjid) financing are far greater than other Mosques (Masjid) due to funding from several sources namely government budgets, donations, and managed businesses, so it creates a higher complexity. Therefore, the internal control system in financial management especially cash in and out at the Paripurna Mosque (Masjid) becomes a crucial point in the mosque's (Masjid's) financial reporting system which is transparent and accountable.

The Method of this study is a qualitative research using a case study strategy in analyzing and applying it.

The result of this study shows that the internal cash control system in Pekanbaru Paripurna Masjid program is still inadequate. There has been a change in mechanism and focus in Paripurna mosque program. Paripurna mosque funding mechanism is no longer for 3 activities namely imarah, ri'ayah and idarah as contained in regional regulation No. 2 of 2016 but now it is only for idarah activity. The disbursement system through SPM is made by the finance department based on a database because there is no direct monitoring on idarah activity in mosque (Masjid).
\end{abstract}

Keywords: Internal control system, cash, mosque, Paripurna Mosque

DOI: $10.7176 /$ RJFA/11-4-02

Publication date: February $29^{\text {th }} 2020$

\section{Introduction}

\subsection{Background of Problem}

Data on the Ministry of Religion's Information System for the Ministry of Religion in 2018 shows that in Indonesia, there are 741,991 mosque and musala buildings. For Muslims, the mosque is a symbol of civilization. Prospering the mosque is not only focused on becoming a center of worship but also as a social, economic, and political activity, so that the prosperity of the mosque is a sign of Islamic civilization in that place advanced.

In the condition of a large quantity of mosques, mosque management at this time still has not received more attention. Most mosques do not understand the importance of having an internal control system function (Andriani, 2011). The practice of mosque financial management is based on trust (trust agency) without having a system to realize that trust (Simanjuntak \& Yeni 2011). Recording and reporting are usually in the form of recording incoming and outgoing money and are only written on the notice board modestly, often even they are not updated. If this is found, the financial reporting system is still in the usual format in accordance with the understanding of the management, the majority of which do not have sufficient competence in managing finances. One contributing factor is that there are no strict rules requiring mosque officials to make financial reports. Administrators only interpret their responsibilities as the mandate of the people (Siskawati, Ferdawati, \& Surya,2016).

Professionally managed financial management can be seen from the internal control system that supports every operational activity of the organization. Internal control system is an important aspect in supporting the success of an organization. It is not only limited to profit-oriented organizations, but also to non-profit organizations. An internal control system that is not carried out properly can lead to financial crime in a nonprofit organization. Some of the evidence (quoted from Duncan, 1999) is a study conducted by Coe and Ellis, a report on The Wall Street Journal, namely crimes committed by Ellen Cook, and interviews with members of the Mississippi Baptist Convention Board.

Coe and Ellis (quoted from Duncan, 1999) conducted a research designed to identify weaknesses in internal control in state, local and nonprofit institutions. They tested 127 cases in North Carolina where states, regions and officials were prosecuted for financial crimes and reported types of controls that were out of place or that were not detailed. They determined that 38.6 percent of crime was the result of improper segregation of duties, 12.6 percent was the result of weak purchasing control, and 11.8 percent was not detected because no audit that was conducted.

Cook was able to divert money because he had control of the audit and violated church policies, namely filling in, checking the request form, and signing it himself. MBCB (quoted from Duncan, 1999) reported that churches in the United States had been victims of fraud or embezzlement of money. In 1996, it was found that the church's finance secretary had embezzled more than $\$ 700,000$ over a three-year period. During this time, each 
individual was believed to be able to take about 33 percent of the church's cash receipts without being detected.

An evidence of financial crime above shows the importance of internal control systems implemented in a non-profit organization such as in mosque (Masjid). Mosque is a non-profit organization, as well as a church that has some of the same characteristics in terms of not understanding the importance of having an internal control system. Some of these characteristics are the absence of overall performance measures, and are usually managed by people who have no special educational background and do not have business management or accounting training (Duncan, 1999).

In order to create a mosque as a center of influence in an advanced civilization in a city, the city of Pekanbaru has a vision of being a "madani" metropolitan city. To realize this, the city government has set up the Paripurna Mosque program as the spearhead of religious and community life development. Paripurna Mosque is an Islamic place of worship that is required for mahdah worship (specifically) and ghairu mahdah worship (worship in general) that has complete facilities and infrastructure in the activities of the field of idarah, imarah, and Ri'ayah and is managed with good management so that it can be made an example of the management of mosque.

Sources of funding in fostering and managing the Paripurna Mosque can be sourced from the Riau Province Regional Revenue and Expenditure Budget (APBD) and Pekanbaru City Revenue and Expenditure Budget (APBD). Other sources are infaq, sadaqah, endowments from legitimate and non-binding Muslims as well as financial income from business service provision and from businesses managed by the Paripurna Mosque Management Agency.

It makes the source of financing for the Paripurna mosque far greater than the mosque in general because the funding is from several sources, namely the government budget, donations, and businesses that are managed. This creates a higher complexity than the mosque in general. Therefore, the internal control system in financial management especially cash in and out at the Paripurna mosque becomes a crucial point in the mosque's transparent and accountable financial reporting system as requested in the mayor's regulation No. 16 Year 2017 CHAPTER XII Article 22, financial accountability must be implemented transparently and accountably. Despite the importance of mosques as religious organizations, Duncan et al. (1999) have shown that accountability in religious organizations is problematic. Therefore, further studies are needed to analyze religious organizations in terms of internal control system research, especially in this case the paripurna mosque which has a high complexity.

\subsection{Problem Formulation}

Lack of an attention to the internal control system in the management of mosque finances makes financial management vulnerable to the risk of fraud in making accountable report.

How is the implementation of the internal control system at Pekanbaru Paripurna mosque?

\subsection{Research Objective}

1. Getting an overview of the internal control system in the financial management of Paripurna mosque

2. Assessing the effectiveness of the internal control system in the financial management of Paripurna mosque

\subsection{Benefits of Research}

1. For Islamic organizations that manage mosques

As a consideration that internal control in a mosque or other place of worship is important. It is useful for the success of an organization.

2. For Academicians

This research is expected to provide additional literature that helps in the development of science.

\section{Literature Review}

\subsection{Paripurna Mosque (Masjid)}

In order to realize the vision of the city of Pekanbaru as a civilized metropolitan city, it is necessary to establish a Paripurna Mosque as the spearhead of religious and community life development. To optimize function of Paripurna Mosque through activities of Idarah, Imarah and Ri'ayah in the context of the duty of government in serving, fostering, and empowering the community, Pekanbaru Government stipulates Pekanbaru City Regulation No. 2 of 2016 concerning Pekanbaru Paripurna Mosque.

\subsubsection{Definition of Paripurna Mosque}

According to Pekanbaru City Regulation Number 2 of 2016 concerning Pekanbaru Paripurna Mosque Chapter I General Provisions Article 1: Plenary Mosque is a Muslim place of worship used for "Mahdhah" (special) worship and "Ghairu Mahdhah" (general worship) which has complete facilities and infrastructure in the activities of Idarah, imarah, and Ri'ayah and managed with good management and can be used as an example in the management of mosque. 
Provision Article 1 stipulates the activities to be carried out in Pekanbaru Paripurna Mosque, namely:

Idarah is the activity of managing the administration, organization, and managing the plenary mosque; Imarah is an activity to enliven and prosper a mosque that is both hablum min Allah (the relationship between the servant and Allah Subhanahu wa Ta'ala) and hablum min al-nas (the relationship between humans); Ri'ayah is maintenance of facilities and infrastructure as well as all assets owned by the mosque to make the mosque as a comfortable, safe, beautiful, clean and orderly place.

2.1.3 Paripurna Management Agency

According to Pekanbaru local Regulation Number 2 of 2016 concerning Pekanbaru Paripurna Mosque Chapter V Organization Article 8:

1. Paripurna Mosque Management Agency consists of the Board of Founders, the Board of Superintendents and the Board of Governors.

2. Service Period of Paripurna Mosque Management Agency is for 5 (five) years and can be re-elected for the following period.

2.1.4 Sources of Financing and Financial Management

According to Local Regulation of Pekanbaru Number 2 of 2016 concerning Pekanbaru Paripurna Mosque Chapter VII Article 12:

1. Sources of Finances to manage of Paripurna mosque are from state Revenue and Expenditure Budget, Riau Province Regional Revenue and Expenditure Budget and Pekanbaru Regional Revenue and Expenditure Budget

2. Other finances are from Infaq, shadaqah, endowments from legitimate and non-binding Muslims as well as financial income coming from business providing services as well as from businesses managed by the Paripurna Mosque Management Agency

3. Paripurna Mosque through the Management Agency can provide incentives and other benefits to the management, employees and other officers whose amount is adjusted to the financial capacity of the mosque

\subsection{Stewardship Theory}

According to Donaldson and Davis in Clarke (2004) stewardship theory is designed for researchers to examine situations where managers in a company as stewards can be motivated to act the best way on their principals, while Chinn in Clarke (2004), says stewardship theory built on philosophical assumptions about human nature, that humans are essentially trustworthy, able to act responsibly, have integrity and honesty with others.

Stewardship theory can be applied to accounting research in public sector organizations such as government organizations and other non-profit organizations that since the beginning of its development, public sector organization accounting has been prepared to meet the information needs of the relationship between stewards and principals (Thorton, 2009).

In this study, the function of stewardship theory is related to the trust that must be maintained by the management of Paripurna mosque in processing funds mandated by the people through Pekanbaru government. Management of Paripurna mosque has the obligation to manage the funds properly as a form of responsibility for the benefit of the people.

\subsection{Internal Control System}

\subsubsection{Definition and Purpose of Internal Control System}

According to Committee of Sponsoring Organization of Treadway Commission (COSO) in Tuanakotta (2013), the definition of Internal Control is a process influenced by the board of directors, management, and other personnel in the entity, which is designed to provide adequate confidence about the achievement of objectives related to operations, reporting, and compliance.

According to Committee on Auditing Procedure of the American Institute of Certified Public Accountants (AICPA) in Tuanakotta (2013), internal control includes the organizational plan and all methods and actions that have been used in the company to secure its assets, check the accuracy and reliability of accounting data, promote operational efficiency, and encourage adherence to policies set by the leadership.

In this study, Pekanbaru Paripurna Mosque needs to apply SPIP because the source of funding in the context of fostering and managing the Paripurna Masjid is sourced from Riau Province Regional Revenue and Expenditure Budget (APBD) and Pekanbaru Regional Revenue and Expenditure Budget (APBD).

2.3.2 Components of Government's Internal Control System

Government regulation no 60 Year 2008 has stated that the component of an internal control system refers to the component of the internal control system that has been practiced in government circles in various countries which include:

a. Control environment

The leadership of government agencies and all employees must create and maintain an environment in the 
whole organization that rises in positive behavior and supports a healthy internal control and management system through enforcement of integrity and ethical values; commitment to competence; conducive leadership; the establishment of an organizational structure that suits the need; delegation of appropriate authority and responsibilities; the formulation and application of sound policies regarding the development of human resources; the realization of the role of an effective government internal control apparatus; and good working relations with relevant government agencies.

b. Risk assessment

Internal control systems must provide an assessment of the risks faced by organizational units both from outside and inside, through risk identification and risk analysis.

c. Control activities

Control activities help to ensure that directives from the leadership of government agencies are implemented. Control activities must be efficient and effective in achieving organizational goals through a review of the performance of the relevant government agencies; human resource development; control over management of information systems; physical or asset control; stipulation and review of indicators and performance measures; separation of functions; authorization of important transactions and events; accurate and timely recording of transactions and events; restrictions on access to resources and records; and good documentation on SPI and important transactions and events.

d. Information and communication

Information must be recorded and reported to the leadership of government agencies and other parties determined. Information is presented in a certain form and means on time so as to enable the leadership of government agencies to carry out their control and responsibilities through providing and utilizing various forms and means of communication as well as managing, developing, and updating information systems continuously.

e. Monitoring

Monitoring must be able to assess the quality of performance over time and ensure that recommendations on audit results and other reviews can be followed up immediately. Internal monitoring and guidance for the implementation of SPIP are carried out to strengthen and support the effectiveness of the implementation of the internal control system. Internal monitoring is one of the activities of the internal control system that functions to conduct an independent assessment of the implementation of the tasks and functions of government agencies, human resource competencies, code of ethics, audit standards, reporting, and peer review. Guidance on the implementation of SPIP includes the preparation of technical guidelines for implementation, socialization, education and training, and guidance and consultation for SPIP, as well as enhancing the competence of auditors of the government's internal supervision apparatus.

\subsection{Cash Internal Control System}

According to Carl S. Warren (2014: 397), Cash (cash) includes coins, banknotes, checks, money orders (money orders or money sent by post which is usually in the form of a bank draft or bank check), and money saved in a bank that can be withdrawn without restriction from the bank concerned.

According to Dwi Martani (2012: 182), basically internal monitoring of cash can be divided into:

1. Internal monitoring of cash received

The principles of internal monitoring are needed to prevent the misappropriation of cash. The principles of good internal monitoring of cash receipts are as follows:

a. Responsibility in handling cash must be clear and permanent.

b. Usually the function of cash receipt and disbursement is separate (except financial institutions).

c. Direct management of cash must be entirely separate from the person making the record and may not interfere in the recording.

d. The donor must get a receipt and cash gets recorded evidence about it.

e. Bank reconciliation must be made by someone who does not handle and does not keep a cash book record.

f. Employees who handle cash must get periodic leave and another one takes over the place when the employee is on leave.

g. All employees who handle cash must make agreements.

h. Cash protective equipment, a cash register, should be used to make it easier for others to check.

2. Internal monitoring of cash issued.

The principles of cash disbursement monitoring are as follows:

a. All expenses must be made by check, except petty cash.

b. All checks must be numbered and the use or cancellation of the number must be clear.

c. All issued checks must be signed by 2 people. 
d. Accountability for cash receipts must be separate from accountability for cash disbursements.

e. The person who signs the check or authorizes the expenses must make an agreement with the company.

f. Bank Reconciliation must be made by someone who does not sign the check or who does not authorize the expenditure.

g. The recording of cash must be separate from the recording of expenditure.

h. Attachments to receipts and other documents must be proven before authorizing the issuance of cash.

i. Checks for salaries must be made in the name of the individual.

j. After payment, all attached documents must be marked or stamped "paid off" to avoid reuse.

$\mathrm{k}$. Officers who manage of cash disbursements must get leave and be replaced by someone else for a while.

1. Ratification of cash disbursement evidence must be made by people who are not related to the task of issuing cash.

m. All petty cash proofs must be written in ink or typed.

\section{Research Method}

\subsection{Place and Time of Research}

The place of this research is Pekanbaru Paripurna Mosque which is spread at the city, sub-district and an administrative village levels in Pekanbaru and it has been conducted in 2019.

\subsection{Methods of Data Collection and Sampling}

\subsubsection{Methods of Data Collection}

This research collects data by doing an observation, interview, and documentation.

1. Observation

Researcher has observed the cash receipts, disbursement procedures and their implementation at Pekanbaru Paripurna Mosque. It is done to see the effectiveness of the implementation of the internal cash control system at Pekanbaru Paripurna Mosque that has run well or not.

2. Interview

An interview has been carried out to know respondents' understanding of a cash internal control system at Pekanbaru Paripurna Mosque. The result of the interview will be transcribed and used to trace and identify matters related to elements of the internal cash control system. The interview technique used by researchers is a semi-structured interview technique.

3. Triangulation

Technical triangulation is done by combining various data collection techniques to get data from the same source (Sugiyono, 2012). In collecting data using triangulation, researchers collect data while examining the credibility of the data at the same time, checking the credibility of the data by using various data collection techniques from various sources. Source triangulation is done by using the same data collection techniques, but at different sources. This collection activity has been carried out not only in one Paripurna mosque but in several sample Paripurna mosques in the city of Pekanbaru. The population in this study is all Plenary Mosques in the city of Pekanbaru both at the city, sub-district and an administrative village levels, totaling 82 mosques.

\subsubsection{Sampling}

Table III.1 shows a population of 82 mosques in all districts in Pekanbaru. Samples to be taken are 12 Paripurna mosques in Tanyan Raya district as there are many Paripurna mosques there.

\subsection{Data Analysis Method}

According to Miles and Huberman (1984) there are three qualitative data analysis techniques, namely data reduction, data presentation, and conclusion drawing. This process continues throughout the research, even before the data is actually collected.

1. Data Reduction

Data reduction is a form of analysis that sharpens, removes unnecessary, focuses on important things, and looks for themes and patterns. Thus, the data that has been reduced can make researchers easier to do further data collection and find it if it is needed. The process of data reduction in this study has been carried out when conducting interview transcripts. The information contained in the interview is certainly a lot and very complex, so the data reduction is needed to make researchers focus on the subject matter.

2. Categorization

The next step is data categorization. Categorization is an effort to sort each unit into parts that have something in common, so conclusions can be drawn. Categorization in this research is done by presenting reduced data and understanding of meaning in tabular form, so that it will be easier for researchers to draw 
conclusions about the subject matter.

3. Taking conclusion

Conclusion is drawn by formulating descriptively based on data obtained and categorized, so that researchers can take an action on a solution to a problem that occurs.

\section{Results and Analysis}

\subsection{Overview}

Based on information obtained from the Finance Section of Tenayan Raya District Office, Pekanbaru, the city government has distributed donation to paripurna mosque through sub-district offices. The donation is managed through the Social Welfare Section (Kesra) of Camat Office. This Welfare Section is directly related to paripurna mosque in the sub-district. Over a period of 5 years, from 2014-2018 there were a number of changes to the policy on aid funds given by the city government to paripurna mosque.

At the beginning of the stipulation, donation from the city government was aimed at 3 activities namely imarah, ri'ayah and idarah. However, finally financial assistance has only been given to paripurna mosque for idarah activities, namely the administration, organization and management of paripurna mosque since 2015. The intended idarah activities are incentives for mosque imams and cleaners, while for Imarah activities (activities to enliven and prosper the mosque) and Ri'ayah (maintenance and maintenance of facilities and infrastructure), mosques are required to independently finance.

The city government distributes financial assistance through the sub-district office, the social welfare section, and then distributes it to Paripurna mosque officials in the sub-district. The funds are directly transferred to each officer's account. Thus, the management of Paripurna mosque donation is carried out entirely by the sub-district office, namely in the social welfare section as seen in the Figure 1

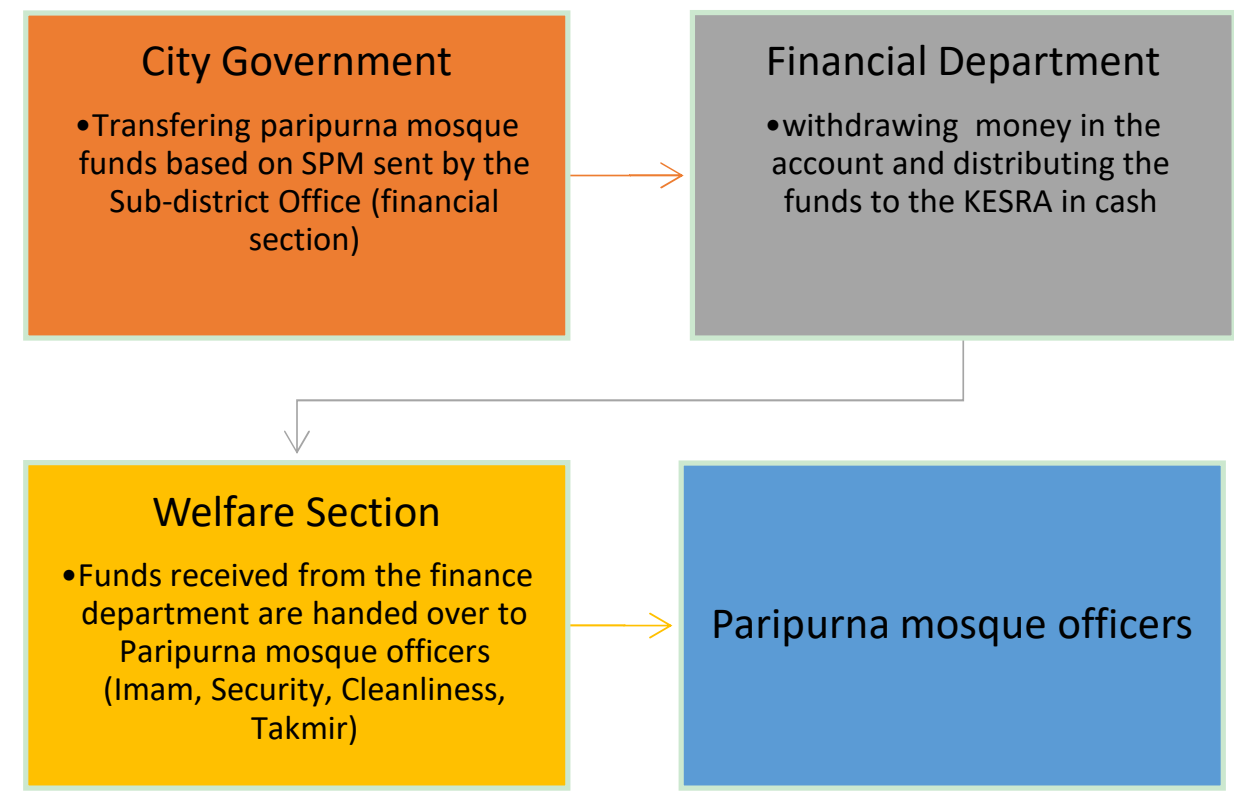

Figure 1 Flow of Disbursement of Paripurna Mosque Funds

Based on this, the object in analyzing the internal control system related to Paripurna mosque funds involves 2 agencies, namely Tenayan Raya sub-district office and 12 Paripurna mosques in Tenayan Raya sub-district.

4.1.1 Tenayan Raya District Office

Tenayan Raya sub-district is a sub-district in Pekanbaru, Riau Province. This district is the result of the expansion of Bukitraya District. This sub-district stretches along the East Cross Road to Teluk Lembu Ujung Village (Teleju). Tenayan Raya is a brick industry area which is managed by the local community, many of which are located in Sail and Kulim. In addition to coal, Tenayan Raya is also famous for the results of cassava plantations that are given household waste fertilizer.

\subsection{Data Reduction}

Data collection technique in this study has used interview with respondents, namely the finance department at Tenayan Raya Sub-District Office and Paripurna mosque management in Tenayan Raya District. Data obtained from interviews related to the cash internal control system at the plenary mosque is quite complex. The result of the interview is written in the interview transcript which will then be reduced because the answers obtained from the respondents do not directly focus on the research problem so that the data reduction process is needed to select 
information and data that is consistent with the focus of the research problem. The process of data reduction is also carried out to see the flow of facts that occur as well as the synchronization of answers from respondents in the financial section at Tenayan Raya District Office with paripurna mosque management in Tenayan Raya District.

\subsection{Categorization}

The next step is data categorization. Categorization is an effort to sort each unit into parts that have something in common, so conclusions can be drawn. Categorization in this research is done by presenting reduced data and understanding of meaning in tabular form, so that it will be easier for researchers to draw conclusions about the subject matter.

Table 4.3 Conformity between theory and facts that occur in the reality

\begin{tabular}{|c|c|c|c|}
\hline No. & $\begin{array}{c}\text { Elements of Cash } \\
\text { Internal Control } \\
\text { System }\end{array}$ & Tenayan Raya District Office & $\begin{array}{l}\text { Paripurna Mosques throughout } \\
\text { Tenayan Raya District }\end{array}$ \\
\hline 1. & $\begin{array}{l}\text { Control } \\
\text { Environment }\end{array}$ & $\begin{array}{l}\text { a. There is a selection of prospective } \\
\text { employees } \\
\text { b. Employees have attended training on } \\
\text { financial management. } \\
\text { c. Camat office has a structure and a } \\
\text { main duty. }\end{array}$ & $\begin{array}{l}\text { a. Selection for mosque } \\
\text { administrators is based on } \\
\text { deliberation and trust. } \\
\text { b. The management is not } \\
\text { equipped with training on } \\
\text { financial management, only } \\
\text { self-taught learning. } \\
\text { c. There is no clear duty for cash } \\
\text { management. }\end{array}$ \\
\hline 2. & Risk Assessment & $\begin{array}{l}\text { a. There is a risk of position occupied by } \\
\text { people who are not competent. } \\
\text { b. The risk of money being disbursed is } \\
\text { not in accordance with the proper rules } \\
\text { c. Misuse of funds } \\
\text { d. The name of the mosque officer who is } \\
\text { no longer working but is still } \\
\text { registered in the district }\end{array}$ & $\begin{array}{l}\text { a. The possibility of error in the } \\
\text { cash balances because it is } \\
\text { managed by more than one } \\
\text { person without clear } \\
\text { boundaries. } \\
\text { b. Reception and recording are } \\
\text { held by one person, creating the } \\
\text { risk of fraud }\end{array}$ \\
\hline 3. & Control Activities & $\begin{array}{l}\text { a. There is no separation of duties } \\
\text { between the cashier and treasurer. } \\
\text { b. Cash receipts are only done by one } \\
\text { officer } \\
\text { c. Disbursement of funds to mosque } \\
\text { officials in cash }\end{array}$ & $\begin{array}{l}\text { a. The recording is done in a } \\
\text { simple daily cash book. } \\
\text { b. Cash is stored directly by the } \\
\text { officer / treasurer of the } \\
\text { mosque in the mosque chest. } \\
\text { c. Cash is directly funded for } \\
\text { mosque operations. } \\
\text { d. There is no file for the } \\
\text { compensation of honor created } \\
\text { by the sub-district office. }\end{array}$ \\
\hline 4. & $\begin{array}{l}\text { Information and } \\
\text { communication }\end{array}$ & $\begin{array}{l}\text { There is no documentation on the } \\
\text { procedure for disbursing paripurna mosque } \\
\text { funds. }\end{array}$ & $\begin{array}{l}\text { Cash receipts and disbursements } \\
\text { that occur during the week are } \\
\text { reported to the mosque } \\
\text { management and the congregation. }\end{array}$ \\
\hline 5. & Monitoring & $\begin{array}{l}\text { There is no routine schedule to monitor the } \\
\text { implementation of the idarah in Paripurna } \\
\text { mosque to see the suitability of people who } \\
\text { receive funds and who work in the field. }\end{array}$ & $\begin{array}{l}\text { Monitoring based on weekly } \\
\text { reports and monthly reports }\end{array}$ \\
\hline
\end{tabular}

\subsection{Presentation of Finding}

4.4.1 Changes in the mechanism for granting government funding to Paripurna mosque

Based on the result of an interview with the Finance Department at Tenayan Raya Sub-district Office, the initial concept of the construction of paripurna mosque is to support the realization of the vision of Pekanbaru City as a madani metropolitan city. From the initial year of the formation of paripurna mosque program in 2014 to 2019 , there have been several changes in the mechanism and form of assistance provided.

4.4.2 Internal Control System of Cash Assistance Funds of Paripurna Mosque at Tenayan Raya District Office Cash management for donation channeled by Pekanbaru Government is located in Tenayan Raya District Office, the Finance Section and Social Welfare Section.

Based on the result of interview with the Finance Department of Tenayan Raya District Office of Pekanbaru 
City regarding the internal control system for the expenditure of paripurna-mosque fund assistance, the obtained findings are as follows

1. The employee who manages paripiurna mosque fund is the State Civil Apparatus (ASN) that has passed the recruitment selection

2. Employees who manage paripurna mosque funds have the ability to manage finances and records because of their accounting education background and often attend training held by the Regional Financial and Asset Management Agency (BPKAD) Pekanbaru City.

3. Employees also have a main duty that refers to the Mayor of Pekanbaru Regulation No. 16 of 2008 concerning the Details of Duties, Functions and Work Procedures of the Regional Secretariat, the Secretariat of the Regional People's Representative Council, and the Subdistricts in Pekanbaru.

4. There has been a separation of duties between the cash receipts function and the recording function, namely treasurer of cash receipts and the accounting department.

5. Procedure for receiving donation is not documented in writing. The finance section states that direct funds are disbursed through bank transfers from the BPKAD of Pekanbaru account to Tenayan Raya District Office account. Furthermore, the Finance Section immediately transfers to the account of the paripurna mosque officers

6. Proof of Cash Entry (BKM) receipt of donation of Paripurna mosque from the city government in the form of a bank statement.

7. Every inclusion of paripurna mosque fund assistance has been accounted for by the treasurer and entered into the district financial statements (attachment 1).

Based on interviews with the Finance Department of Tenayan Raya District Office in Pekanbaru City, the obtained findings are as follows

1. The employee who manages paripurna mosque fund is the State Civil Apparatus (ASN) that has passed the recruitment selection.

2. Employees who manage paripurna mosque funds have the ability to manage finances and records because of their accounting education background and often attend training held by the Regional Financial and Asset Management Agency (BPKAD) Pekanbaru City.

3. Employees also have a main duty that refers to the Mayor of Pekanbaru Regulation No. 16 of 2008 concerning Details of Duties, Functions and Work Procedures of the Regional Secretariat, the Secretariat of the Regional Representatives Council, and Sub-Districts in Pekanbaru City Government.

4. There has been a separation of duties between the cash disbursement function and the recording function, namely the treasurer of cash disbursements and the accounting department.

5. Procedure for receiving donation is not documented in writing. The finance department states that, direct funds disbursement is through bank transfers from the Pekanbaru City BPKAD account to Tenayan Raya District Office account. Furthermore, the Finance Section immediately transfers to the account of paripurna mosque officers.

6. Proof of Cash Out (BKK) spending fund assistance to paripurna mosque is in the form of a bank statement

7. There is a record of the honorarium of paripurna mosque officers every month which is authorized by the authorized official (appendix 2).

8. Every expenditure for fund assistance of pripurna mosque has been accounted for by the treasurer and included in the sub-district financial statements (appendix 1).

9. There is regular monitoring from the inspectorate, BPKP and BPK on the financial statements of the subdistrict office.

4.4.3 Internal Control Systems of paripurna mosque cash in Tenayan Raya sub-district

The funding source for paripurna mosque in Tenayan Raya sub-district comes from infaq, shodaqoh and wakaf of the congregation. Cash management is carried out by the mosque management / takmir.

Based on interviews with mosque management regarding the cash control internal control system, the obtained findings are as follows

1. There is a mosque that does not make a selection of officers who manage mosque finances. There are no special requirements in selecting officers. Officers are chosen based solely on management and community consultations.

2. Each board has worked according to their abilities. The elected management has been a capable person in managing mosque finances.

3. There are mosques having never made any provision or special guidance for the administrators in relation to the finance. The board only has a basic skill in managing finances, such as keeping records in the daily cash book for each existing cash receipt.

4. There are mosques in which cash receipt transactions are carried out by more than one officer. Cash receipts obtained from the congregation in the form of infaq, shodaqoh and endowments are counted together by all mosque administrators and immediately recorded by the officer (treasurer). Sometimes if 
the officer is unable, he is replaced by another administrator

5. There is a mosque in which the responsibility for conducting transactions, recording, and storage is given to different people but there are still mosques in which the function of cash receipts and recording is done by one officer as this is based on the principle of trust.

6. All mosques have clear duties and responsibilities according to their position in the organizational structure, namely the main imam, second imam, mosque officer / treasurer, mosque secretary, security officer. However, the structure and duties are not written.

7. All mosques have recorded cash receipts in a simple daily cash book

8. There is a mosque that does not keep any cash receipts, because the nominal cash receipts are small in number - it only comes from infaq, shodaqoh and wakaf of congregation - so that each cash receipt is kept only by the officer / treasurer of the mosque in the mosque chest and usually also directly used for mosque operations.

9. Every cash receipt is not accompanied by documents / proof of cash receipt, because cash only comes from infaq, shodaqoh and endowments. For receipts from city government grants, a salary slip is made by the subdistrict office, but not copied by the mosque since transactions are more often done through bank transfers.

10. All mosques do a matching physical amount of cash in hand with a periodic amount of cash according to records, once a week or every Friday. The reporting is not only announced directly to all the administrators and worshipers after Friday prayers in congregation but it is also written on the mosque notice board.

11. There are regular reports on cash receipts conducted every month and have been accounted for by authorized officials, namely the mosque's chairman and secretary (appendix 4). However, not all mosques do it.

Based on an interview with the mosque management regarding the cash control internal control system, the obtained findings are as follows:

1. Selection of candidates for the management of the cash disbursement section is based on the requirements demanded by their work, as well as the cash receipt officer. Officers for cash receipts and cash disbursements are carried out by the same person, the treasurer of the mosque.

2. There is a mosque in which all treasury transactions are carried out solely by the treasurer from beginning to end. However, more treasurers of mosque are assisted by secretaries or other administrators in managing cash disbursements.

3. All mosques have issued cash disbursements after obtaining approval from the authorized official / mosque leader. However, written authorization is not carried out.

4. All mosques have recorded cash disbursement transactions in a simple daily cash register

5. All mosques have recorded cash disbursement transactions based on transaction evidence. However, there are also cash disbursements that are not accompanied by proof of the transaction. Usually cash disbursements that have proof are purchase transactions to stores (appendix 5).

6. Officers are equipped with tools that prevent theft of cash in hand such as metal cupboards. However, there are still mosques that hold their own cash.

7. Regular monitoring has been carried out by all management regarding expenses. It is the same as cash receipts. all cash receipts and disbursements that occur during the week are reported to the mosque's management and worshipers. Meanwhile, written reports are conducted monthly and are known by the mosque's chairman and secretary (appendix 4). However, not all mosques do it

\section{Conclusions and Suggestions}

\subsection{Conclusion}

Based on this research, it can be concluded that the internal cash control system in paripurna mosque program is still inadequate. This is based on the following points:

\section{1. (Enviroment Control)}

There has been a change in mechanism and focus in paripurna mosque program. Paripurna mosque funding mechanism is no longer for 3 activities namely imarah, ri'ayah and idarah as contained in local regulation no 2 of 2016. But now financial assistance is only given to paripurna mosque for idarah activities only, namely administrative, organizational and management implementation activities such as salaries for imam of mosque, janitors and security. This change is not stated in the latest regulations, so this policy does not yet have a legal rule. For the activities of Imarah (activities to enliven and prosper the mosque) and Ri'ayah (maintenance and maintenance of facilities and infrastructure), the mosque is required to finance independently.

2. (Risk Assesment)

The disbursement of funds through SPM system created by the finance department based on the database causes no direct monitoring of idarah work in the mosque. This raises the risk of the possibility 
of a name that is still registered in the sub-district which no longer works in the mosque or being carried out by someone else.

3. (Control Activities)

Controlling activity over Paripurna mosque funds is considered to be good enough. This starts from receiving funds through sub-district account, so that it becomes transparent and can be accounted for. In terms of expenditures, funds are disbursed in cash to mosque officials. This can be a control to ensure that the recipient is a person contained in sub-district data.

4. (Information and communication)

In the sub-district office, there is no SOP that regulates the flow of receipts and disbursements of funds for Paripurna mosque program budget.

5. (Monitoring)

There is no schedule for monitoring the implementation of idarah program

\subsection{Suggestion}

1. A legal determination on the change in mechanism and focus of paripurna mosque program is needed. It is as a basis of a clear legal rule of a current financial management of paripurna mosque program.

2. Monitoring of the implementation of the idarah program is needed to see how effective the program of idarah is.

3. SOP (standard operation procedure) needs to be made on the financial management of paripurna mosque program funds in the sub-district for clarity of the effectiveness and efficiency of the policies made.

\section{References}

Andriani, C. (2011). “Analisis Perbedaan Kualitas Sistem Pengendalian Intern Masjid ditinjau dari Ukuran Masjid dan Tipe Organisasi Islam Pengelola Masjid”. Skripsi Program S1 Fakultas Ekonomi Universitas Dipenegoro Semarang

Carl S. Warren, dkk. (2014). “Accounting Indonesia Adaptation”. Jakarta: Salemba Empat

Duncan, J. B., Flesher, D. L., and Stocks, M. H. (1999), "Internal Control Systems in US Churches: An Examination of the Effects of Church Size and Denomination on Systems of Internal Control", Accounting, Auditing \& Accountability Journal, 12 (2), 142-163.

E.Kieso, Donald, Jerry, Weygandt and Teery D. Warfield. (2017). “Akuntansi Keuangan Menengah Intermediate Accounting (Edisi IFRS)". Jakarta: Salemba Empat

Effendi Rizal. (2013). Accounting Principles 'Prinsip-prinsip Akuntansi Berbasis SAK ETAP”. Edisi Revisi. Jakarta : PT. Rajagrafindo Persada

Martani, Dwi. (2012). "Akuntansi Keuangan Menengah berbasis PSAK”. Jakarta: Salemba.

Mulyadi. (2014). “Auditing Buku 1 Edisi Keenam”. Jakarta: Salemba Empat

Romney, Marshall B. dan Steinbart, Paul Jhon. (2017). "Sistem Informasi Akuntansi (Diterjemahkan oleh Kikin dan Novita". Jakarta: Salemba Empat

Simanjuntak, D. A., \& Januarsi, Y. (2011). “Akuntabilitas dan Pengelolaan Keuangan di Masjid”. In Simposium Nasional Akuntansi XIV (pp. 21-22). Banda Aceh: Fakultas Ekonomi Univesitas Syiah Kuala.

Siskawati, E., Ferdawati, \& Surya, F. (2016). "Bagaimana Masjid Dan Masyarakat Saling Memakmurkan? Pemaknaan Akuntabilitas Masjid”. Jurnal Akuntansi Multiparadigma JAMAL, 7(1), 70-80.

Sugiyono. (2013). Metode Penelitian Kuantitatif, Kualitatif dan R\&D. Bandung: Alfabeta

Thornton D. Deborah. (2009). "Stewardship in Government Spending:Accountability, Transparency, Earmarks, and Competition". Policy Study, No. 09-1, Public Interest Institute.

Tuanakotta, Theodorus M. (2013). “Audit Berbasis ISA (International Standards on Auditing)”.Jakarta: Salemba Empat.

Tugiman, Hiro, (2008), "Standar Profesional Audit Internal”. Bandung: Kanisius

Peraturan Pemerintah Nomor 60 Tahun 2008 Tentang "Sistem Pengendalian Intern Pemerintah"

Peraturan Daerah Kota Pekanabaru No 2. 2016. Tentang "Masjid Paripurna Kota Pekanbaru"

Peraturan Wali Kota Pekanbaru No 16. 2017. Tentang "Pedoman Pengelolaan Masjid Paripurna Kota Pekanbaru" 